\title{
- Effect of Integrated Nutrient Management on Essential Oil (Volatile Oil) of Coriander (Coriandrum sativum L.)
}

\section{Sunita Jhariya ${ }^{1}$, Aruna Jain ${ }^{2}$}

'Research Scholar, Department of Botany, Sarojini Naidu Govt. Girls P.G. (Autonomous) College, Shivaji Nagar, Bhopal (MP), India; 2Assistant Professor Botany, Department of Botany, Sarojini Naidu Govt. Girls P.G. (Autonomous) College, Shivaji Nagar, Bhopal (MP), India.

\section{ABSTRACT}

Aim: The experiment was intended to find out the effect of Integrated Nutrient Management on Essential oil (Volatile oil) of Coriander (Coriandrum sativum L.).

Methodology: The experiment was laid out in a randomized block design with 8 treatments using chemical fertilizers (NPK), vermicompost and biofertilizers (Azotobacter and Phosphate Solubilizing Bacteria sp. Pseudomonas strata) in different combinations including one control treatment.

Results: The results indicated that volatile oil percentage and percentage of different compounds i.e. Linalool, Geraniol, apinene and $B$ - pinene in volatile oil of Coriandrum sativum L. was recorded significantly higher in T7 treatment compared to control treatment at different growth stages.

Conclusion: From the analysis of results it can be concluded that integrated use of biofertilizers, chemical fertilizers and vermicompost is the best combination for the Coriander (Coriandrum sativum L.) crop.

Key Words: Biofertilizers, Chemical Fertilizers, Vermicompost, Integrated Nutrient Management, Volatile oil, Coriandrum sativum

\section{INTRODUCTION}

India is known all over the world as "The Home of Spices". The fame of Indian spices is older than the recorded history. The term spice applies to natural plant or vegetable products or mixtures in whole or ground form, which are used for imparting flavor, aroma and piquancy to the food items. Spices are made up of many parts of a plant such as roots, bark, flowers, fruits, leaves etc. with distinct flavor and taste (www.mccormickscienceinstitute.com). Coriander (Coriandrum sativum L.) an annual herb of the parsley family (Apiaceae), is native to the Mediterranean region and is extensively grown in Bangladesh, India, Russia, central Europe and Morocco and has been cultivated since human antiquity (Small,1997 and Bhuiyan et al., 2009). The plant is grown widely all over the world for seed, as a spice, or for essential oil production (Lawrence, 1993). All part of the plants is edible but the fresh leaves and the dried seeds are the most common parts used in cooking. Coriander contains an essential oil (0.03-2.6\%). The essential oil of coriander is also called volatile oil. It has strong effects on the nervous system and is therefore widely used by aroma therapists and herbologists as a sedative, spasmolytic and local anaesthetic. It is also used against many skin complaints, mostly in the form of tea tree oil. The different parts of this plant contain monoterpenes, limpnene, a-pinene, g-terpinene, p-cymene, citronellol, borneol, camphor, coriandrin, geraniol, dihydrocoriandrin, coriandrons A-E, flavonoids and essential oils (Farooq Anwar et al., 2011 and Nadeem et al, 2013). Various parts of this plant such as seed, leaves, flower and fruit, possess antioxidant activity, anti-diabetic activity, anti-mutagenic activity, anthelmintic activity, sedative - hypnotic activity, anticonvulsant activity, diuretic activity, cholesterol lowering activity, protective role against lead toxicity, antifungal

\section{Corresponding Author:}

Sunita Jhariya, Research Scholar, Department of Botany, Sarojini Naidu Govt. Girls P.G. (Autonomous) College, Shivaji Nagar, Bhopal (MP), India; Mob: 8989457054; Email: sunita.jhariya@gmail.com

ISSN: 2231-2196 (Print)

Received: 27.06 .2017
ISSN: $0975-5241$ (Online)

Revised: 20.07 .2017
DOI: $10.7324 / I J C R R .2017 .9173$

Accepted: 09.08.2017 
activity, anti-feeding activity, anticancer activity, anxiolytic activity, hepatoprotective activity, anti-protozoal activity, anti-ulcer activity, post-coital anti-fertility activity, heavy metal detoxification (Momin et al., 2012). According to Polo and De Bravo (2006) Geraniol has anti-tumor activity against human hepatocarcinoma cell line Hep G2, human pancreatic cancer cells (Jin et al., 2013) and anti-proliferative effects on human colon cancer cells (Carnesecchi et al., 2002). Chen et al., (2015) found that liver cancer cell growth was inhibited by the use of $\alpha$ - pinene. Silva et al., (2012) found that $\alpha$ and $\beta$ - pinene has antimicrobial activities against bacterial and fungal cells. All parts of the plant contain essential oils that give the green plant a characteristic smell, which is similar to that of bugs. This smell is caused by different aldehydic components of the essential oil present in the green plant.

\section{MATERIAL AND METHODS}

The field experiment was conducted in farmer's field at village Raghogarh, Distt. Guna, Madhya Pradesh. The experiment was conducted in a randomized block design (RDB) with 8 treatments and three replicas of each, using vermicompost, chemical fertilizers (NPK) and biofertilizers (Azotobacter and Phosphate Solubilizing Bacteria) in different combinations including one control treatment. The treatments were $\mathrm{T}_{1}$ - Biofertilizers $(250 \mathrm{~g}$ Azotobacter $+250 \mathrm{~g}$ PSB ha- $\left.{ }^{-1}\right), \mathrm{T}_{2}-$ Vermicompost $5 \mathrm{t} \mathrm{ha}^{-1}, \mathrm{~T}_{3}-$ Chemical Fertilizers (60:30:30 kg NPK ha-1 $), \mathrm{T}_{4}$ - Biofertilizers + Vermicompost ( $125 \mathrm{~g}$ Azotobacter $+125 \mathrm{~g} P S B+5 \mathrm{t}$ Vermicompost ha ${ }^{-1}$ ), $\mathrm{T}_{5}$ - Vermicompost + Chemical Fertilizers [5t Vermicompost ha- ${ }^{-1}+50 \%$ NPK ha-1 $\left.(\mathrm{RDF})\right], \mathrm{T}_{6}$ - Chemical Fertilizers + Biofertilizers [50\% NPK ( RDF as 30:15:15 kg per ha ${ }^{-1}$ ) $+125 \mathrm{~g}$ Azotobacter $+125 \mathrm{~g}$ PSB ha $\left.{ }^{-1}\right], \mathrm{T}_{7}$ - Biofertilizers + Vermicompost + Chemical Fertilizers $[125 \mathrm{~g}$ Azotobacter + 125g PSB ha-1 $+5 \mathrm{t}$ Vermicompost ha ${ }^{-1}+50 \%$ NPK (RDF as 30:15:15 $\left.\left.\mathrm{kg} \mathrm{ha}^{-1}\right)\right], \mathrm{T}_{8}-$ Control (No Treatment).

\section{Estimation of Essential oil (volatile oil)}

Estimation of essential oil of Coriandrum sativum was performed on vegetative parts and on harvested dried seeds. The extraction of volatile oil was done by hydrodistilation for 4 hour, using Clevenger's apparatus to know the percentage of volatile oil and analysis of volatile oil was done by using GC - MS (Gas Chromatography - Mass spectrometry) to know the composition and to know the quantity of each component in volatile oil as described by Masada, 1976 .

The oil dried over anhydrous sulphate solution, and stored at $4^{\circ} \mathrm{C}$ up to analysis by GC-MS.

\section{Analysis of essential oil}

Analysis of essential oil was done by using Gas Chromatography with Mass Spectrometer as described by James and Martin (1951) to know the composition of oil and the quantity of each composition. Analysis of essential oil for chemical composition was carried out using an Agilent Technologies $6890 \mathrm{~N}$ network gas Chromatographic (GC) system equipped with 5975 inert XL mass selective detector and $7683 \mathrm{~B}$ series auto injector Agilent - Technologies. A sample volume of $1.0 \mu \mathrm{l}$ was injected, applying split mode (split ratio 100:1), into HP-5 MS capillary column (30m $\times$ $0.25 \mathrm{~mm}$ ), film thickness $0.25 \mu \mathrm{m}$.

The initial column temperature was set at $80^{\circ} \mathrm{C}$ and raised to $220^{\circ} \mathrm{C}$ by the rate of $4^{\circ} \mathrm{C} / \mathrm{min}$. The initial and final column temperatures were held for 3 and $10 \mathrm{~min}$, respectively. The operating temperatures for detector and injector were $220^{\circ} \mathrm{C}$ and $290^{\circ} \mathrm{C}$, respectively. The mobile phase used was helium at a flow rate of $1.5 \mathrm{ml} / \mathrm{min}$. An electron ionization (EI) system, with ionization energy $(70 \mathrm{e})$ was used for GC-MS detection. Mass scanning range was varied over 50 to $550 \mathrm{~m} / \mathrm{z}$. the injector and MS transfer line temperature were $220^{\circ} \mathrm{C}$ and $290^{\circ} \mathrm{C}$, respectively. The essential oil compounds were identified on the basis of matching their retention indices in relation to n-alkenes $\left(\mathrm{C}_{9}-\mathrm{C}_{24}\right)$ and moreover with those of authentic compounds or published data (Minica et al., 2004, Vagionas et al., 2007). Beside the comparison of MS spectral data of the compounds with those from NIST mass spectral library was also applied to authenticate the compounds (Adams, 2001).

\section{RESULTS}

Various nutrient schedules influenced the essential oil \% and $\%$ of different compounds in essential oil (volatile oil) of coriander at different growth stages. (Table and Fig. 1, 2, 3)

The combined application of BF 250g/ha +VC @ 5t/ha + $50 \%$ NPK RDF as $30: 15: 15 \mathrm{~kg} / \mathrm{ha}\left(\mathrm{T}_{7}\right)$ was found to be superior when compared to control, in registering the maximum essential oil (\%) in vegetative parts of the plant at different growth stages, while in dried seeds after harvest, it was also superior over control, when compared to other treatments it was found non-significant.

The amount of different compounds ( $\alpha$-pinene, $\beta$-pinene, Linalool and Geraniol) within the essential oil were also recorded higher in combined application of BF @ 250g + VC (a) 5t/ha + 50\% NPK RDF as 30:15:15 kg/ha $\left(\mathrm{T}_{7}\right)$ when compared to control $\left(\mathrm{T}_{8}\right)$ at different growth intervals.

\section{DISCUSSION}

The essential oil $\%$ and $\%$ of different compounds in essential oil (volatile oil) of Coriander was found maximum in $\mathrm{T}_{7}$ treatment with the application of $\mathrm{BF}+\mathrm{VC}+\mathrm{CF}$. The better essential oil (\%) in plants might be due to increased 
Table 1: Effect of biofertilizers, vermicompost and chemical fertilizers on volatile oil \% and \% of different compounds in volatile oil of $C$. sativum at vegetative stage

\begin{tabular}{|c|c|c|c|c|c|c|c|}
\hline \multirow{2}{*}{$\begin{array}{l}\text { Plot } \\
\text { No. }\end{array}$} & \multirow[t]{2}{*}{ Treatments } & & \multirow{2}{*}{$\begin{array}{l}\text { Volatile } \\
\text { oil \% }\end{array}$} & \multicolumn{4}{|c|}{$\%$ of different compounds in volatile oil } \\
\hline & & & & $\alpha$-pinene & $\beta$-pinene & Linalool & Geraniol \\
\hline $\mathrm{T}_{1}$ & BF & & 0.12 & 0.78 & 0.24 & $7 \cdot 39$ & 25.65 \\
\hline $\mathrm{T}_{2}$ & VC & & 0.10 & 1.32 & 0.46 & 8.12 & 16.26 \\
\hline $\mathrm{T}_{3}$ & $\mathrm{CF}$ & & 0.12 & 0.24 & 0.33 & 7.00 & 22.54 \\
\hline $\mathrm{T}_{4}$ & $\mathrm{BF}+\mathrm{VC}$ & & 0.14 & 0.94 & 0.21 & 10.16 & 23.81 \\
\hline $\mathrm{T}_{5}$ & $\mathrm{VC}+\mathrm{CF}$ & & 0.12 & 0.76 & 0.23 & 6.38 & 22.18 \\
\hline $\mathrm{T}_{6}$ & $\mathrm{CF}+\mathrm{BF}$ & & 0.12 & 0.89 & 0.19 & $5 \cdot 7$ & 28.37 \\
\hline $\mathrm{T}_{7}$ & $\mathrm{BF}+\mathrm{VC}+\mathrm{CF}$ & & 0.17 & 1.46 & 0.62 & 11.45 & 23.43 \\
\hline $\mathrm{T}_{8}$ & NT & & 0.07 & 0.3 & 0.15 & 4.14 & 15.45 \\
\hline SA & Mean & & .1200 & .8362 & .3038 & $7 \cdot 5425$ & 22.2113 \\
\hline SA & Variance & & .001 & .184 & .026 & 5.585 & 19.291 \\
\hline SA & SD & & .02878 & .42908 & .16035 & 2.36323 & 4.39216 \\
\hline SA & $\mathrm{SE}_{\mathrm{m}}$ & & .01018 & .15170 & .05669 & .83553 & 1.55286 \\
\hline \multirow[t]{2}{*}{ SA } & \multirow{2}{*}{$\begin{array}{l}95 \% \text { confidence } \\
\text { Interval of the difference }\end{array}$} & Lower & .0959 & .4775 & .1697 & $5 \cdot 5668$ & 18.5393 \\
\hline & & Upper & .1441 & 1.1950 & .4378 & $9 \cdot 5182$ & 25.8832 \\
\hline
\end{tabular}

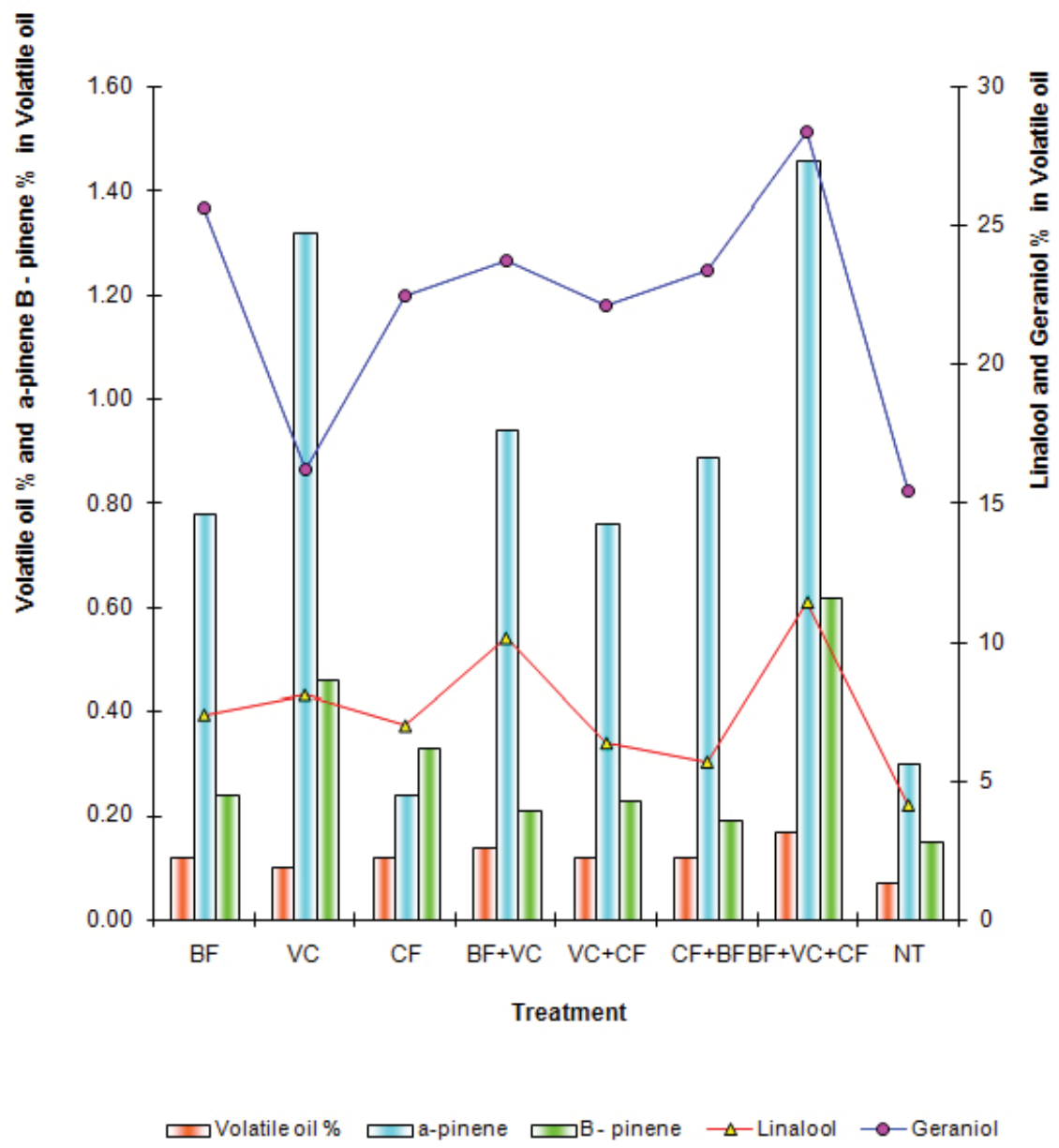

Figure 1: Effect of biofertilizers, vermicompost and chemical fertilizers on volatile oil $\%$ and $\%$ of different compounds in volatile oil of $C$. sativum at vegetative stage. 
Table 2: Effect of biofertilizers, vermicompost and chemical fertilizers on volatile oil \% and \% of different compounds in volatile oil of $C$. sativum at harvest stage

\begin{tabular}{|c|c|c|c|c|c|c|c|}
\hline \multirow[t]{2}{*}{ Plot No. } & \multirow[t]{2}{*}{ Treatments } & & \multirow{2}{*}{$\begin{array}{l}\text { Volatile } \\
\text { oil } \%\end{array}$} & \multicolumn{4}{|c|}{$\%$ of different compounds in volatile oil } \\
\hline & & & & $\alpha$-pinene & $\beta$-pinene & Linalool & Geraniol \\
\hline $\mathrm{T}_{1}$ & $\mathrm{BF}$ & & 0.12 & 1.62 & 0.20 & 22.01 & 11.43 \\
\hline $\mathrm{T}_{2}$ & VC & & 0.12 & 1.56 & 0.17 & 20.55 & 11.23 \\
\hline $\mathrm{T}_{3}$ & $\mathrm{CF}$ & & 0.12 & 1.42 & 0.19 & 20.58 & 13.40 \\
\hline $\mathrm{T}_{4}$ & $\mathrm{BF}+\mathrm{VC}$ & & 0.10 & 1.59 & 0.17 & 21.76 & 9.26 \\
\hline $\mathrm{T}_{5}$ & $\mathrm{VC}+\mathrm{CF}$ & & 0.12 & 1.21 & 0.15 & 31.63 & 8.40 \\
\hline $\mathrm{T}_{6}$ & $\mathrm{CF}+\mathrm{BF}$ & & 0.10 & 1.48 & 0.14 & 33.30 & 10.75 \\
\hline $\mathrm{T}_{7}$ & $\mathrm{BF}+\mathrm{VC}+\mathrm{CF}$ & & 0.14 & 1.83 & 0.22 & 34.29 & 14.45 \\
\hline $\mathrm{T}_{8}$ & NT & & 0.10 & 0.82 & 0.12 & 11.95 & 8.05 \\
\hline SA & Mean & & .1150 & 1.4412 & .1700 & 24.5088 & 10.8712 \\
\hline SA & Variance & & .000 & .094 & .001 & 60.900 & 5.189 \\
\hline SA & SD & & .01414 & .30722 & .03295 & 7.80384 & 2.27785 \\
\hline SA & $\mathrm{SE}_{\mathrm{m}}$ & & .00500 & .10862 & .01165 & 2.75907 & .80534 \\
\hline \multirow[t]{2}{*}{ SA } & $\begin{array}{l}95 \% \text { confidence } \\
\text { Interval of the differ- }\end{array}$ & Lower & .1032 & 1.1844 & .1425 & 17.9846 & 8.9669 \\
\hline & ence & Upper & .1268 & 1.6981 & 1975 & 31.0329 & 12.7756 \\
\hline
\end{tabular}

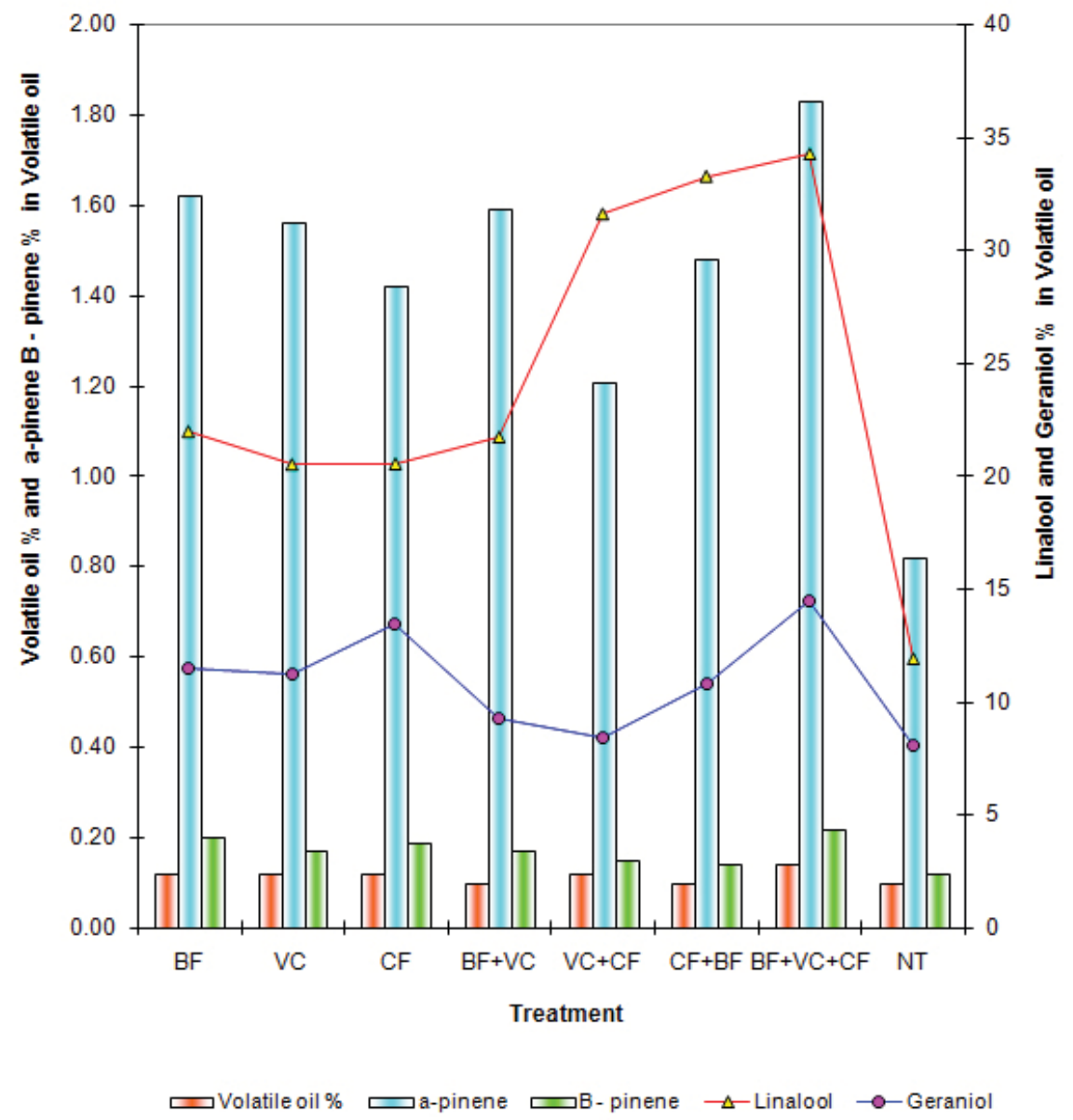

Figure 2: Effect of biofertilizers, vermicompost and chemical fertilizers on volatile oil $\%$ and $\%$ of different compounds in volatile oil of $C$. sativum at harvest stage. 
Table 3: Effect of biofertilizers, vermicompost and chemical fertilizers on volatile oil \% and \% of different compounds in volatile oil of $C$. sativum (dry seeds) after harvesting

\begin{tabular}{|c|c|c|c|c|c|c|c|}
\hline \multirow[t]{2}{*}{ Plot No. } & \multirow[t]{2}{*}{ Treatments } & & \multirow{2}{*}{$\begin{array}{l}\text { Volatile } \\
\text { oil } \%\end{array}$} & \multicolumn{4}{|c|}{$\%$ of different compounds in volatile oil } \\
\hline & & & & $\alpha$-pinene & $\beta$ - pinene & Linalool & Geraniol \\
\hline $\mathrm{T}_{1}$ & $\mathrm{BF}$ & & 0.5 & $4 \cdot 30$ & 0.23 & 85.49 & 0.56 \\
\hline $\mathrm{T}_{2}$ & VC & & 0.4 & 4.14 & 0.24 & 85.80 & 0.69 \\
\hline $\mathrm{T}_{3}$ & CF & & 0.4 & 4.03 & 0.25 & $83 \cdot 37$ & 0.56 \\
\hline $\mathrm{T}_{4}$ & $\mathrm{BF}+\mathrm{VC}$ & & 0.5 & 6.60 & 0.66 & 83.16 & 0.49 \\
\hline $\mathrm{T}_{5}$ & $\mathrm{VC}+\mathrm{CF}$ & & 0.5 & $5 \cdot 51$ & 0.51 & 86.01 & 0.56 \\
\hline $\mathrm{T}_{6}$ & $\mathrm{CF}+\mathrm{BF}$ & & 0.4 & 8.26 & 0.56 & 82.91 & 0.72 \\
\hline $\mathrm{T}_{7}$ & $\mathrm{BF}+\mathrm{VC}+\mathrm{CF}$ & & 0.5 & 8.76 & 0.71 & 86.36 & 1.00 \\
\hline $\mathrm{T}_{8}$ & NT & & 0.3 & 2.68 & 0.21 & 80.97 & 0.37 \\
\hline SA & Mean & & .4375 & $5 \cdot 5350$ & .4212 & 84.2588 & .6188 \\
\hline SA & Variance & & .006 & 4.693 & .044 & $3 \cdot 715$ & .036 \\
\hline SA & SD & & .07440 & 2.16625 & .21074 & 1.92746 & .18879 \\
\hline SA & $\mathrm{SE}_{\mathrm{m}}$ & & .02631 & $\cdot 76588$ & .07451 & .68146 & .06675 \\
\hline \multirow[t]{2}{*}{ SA } & $95 \%$ confidence & Lower & .3753 & 3.7240 & $.245^{1}$ & 82.6474 & .4609 \\
\hline & $\begin{array}{l}\text { Interval of the } \\
\text { difference }\end{array}$ & Upper & .4997 & $7 \cdot 3460$ & .5974 & 85.8701 & $\cdot 7766$ \\
\hline
\end{tabular}

Abbreviations:- NT - No Treatment, BF - Biofertilizers, VC - Vermicompost, CF- Chemical Fertilizers, SD- Standard Deviation, SEm - Standard Error mean, SA - Statistical Analysis, INM - Integrated Nutrient Management, N - nitrogen, P - phosphorus, K- Potassium, PSB - phosphate solubilising bacteria.

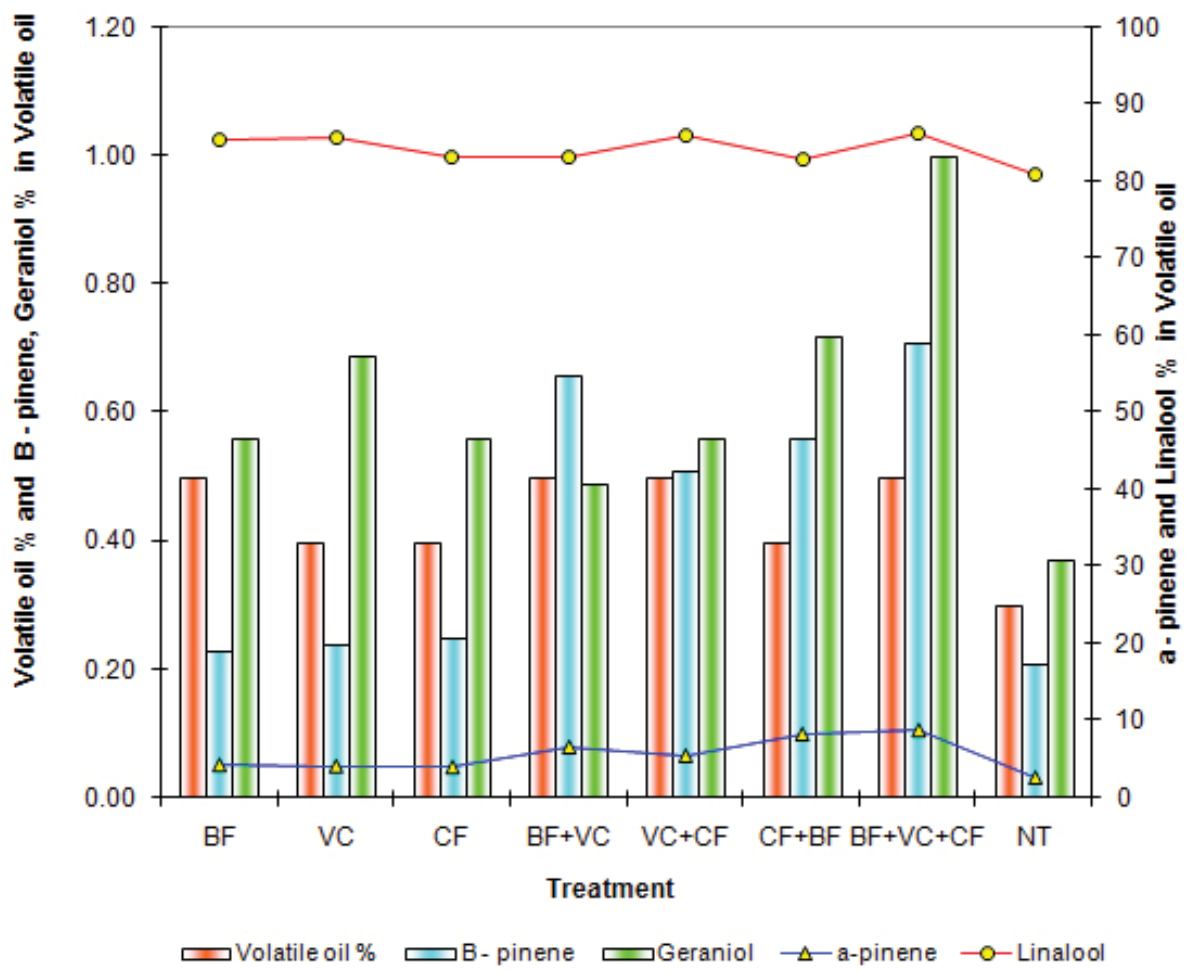

Figure 3: Effect of biofertilizers, vermicompost and chemical fertilizers on volatile oil \% and \% of different compounds in volatile oil (dried seeds) of C. sativum after harvesting. 
vegetative growth due to integrated nutrient management that results in better photosynthetic activity and it results in increased volatile oil (\%) in Coriander plants at different growth intervals.

The study by Kumar T. Senthil et al. (2009) also revealed that the combined application of nitrogen and phosphorus along with biofertilizers increased the essential oil yield in Devana (Artimisia pallens Wall). The results are in conformity with Srinivasan et al. (2005) in black pepper, Garg (2007) in fennel (Foeniculum vulgare Mill.), Gharib et al. (2008) in Sweet Marjoram (Majorana hortensis).

\section{CONCLUSION}

The findings revealed that the application of BF $250 \mathrm{~g} / \mathrm{ha}+$ VC@ $@ 5 \mathrm{t} / \mathrm{ha}+50 \%$ NPK RDF was effective and it significantly improved the essential (volatile) oil (\%) and percent of different compounds in essential oil of Coriander. Therefore, the nutrient needs can best be met through integrated nutrient management (INM). The concept of INM aims to increase the efficiency of use of all nutrient sources, the soil resources, mineral fertilizers, organic manures and recyclable wastes or biofertilizers. It can be concluded by these findings that biofertilizers and vermicompost along with chemical fertilizers (RDF) should be applied to Coriander for better quality crop, as already reported by Darzi and Hadi (2012) in coriander (Coriandrum sativum L.).

\section{ACKNOWLEDGEMENT}

Authors acknowledge the immense help received from the scholars whose articles are cited and included in references of this manuscript. The authors are also grateful to authors / editors / publishers of all those articles, journals and books from where the literature for this article has been reviewed and discussed.

\section{REFERENCES}

1. Adams, R. P. (2001). Identification of essential oil components by gas chromatography/quadrupole mass spectroscopy. Carol Stream IL, USA: Allured.

2. Bhuiyan MNI, J Begum and M Sultana (2009). Chemical composition of leaf and seed essential oil of Coriandrum sativum L. from Bangladesh. Bangladesh J. Pharmacol., 4: 150 - 153.

3. Carnesecchi S, A Bradaia, B Fischer, D Coelho, M Schöller-Guinard, F Gosse and F Raul (2002). Perturbation by geraniol of cell membrane permeability and signal transduction pathways in human colon cancer cells. J Pharmacol Exp Ther, 303 (2): 711 - 5.

4. Chen Weiqiang, Ying Liua, Ming Lia, Jianwen Maoa, Lirong Zhanga, Rongbo Huanga, Xiaobao Jina and Lianbao Yeb (2015). Anti-tumor effect of $\alpha$-pinene on human hepatoma cell lines through inducing G2/M cell cycle arrest. Journal of Pharmacological Sciences, 127 (3): 332-338
5. Darzi Mohammad Taghi and Mohammadreza Haj Seyed Hadi (2012). Effects of organic manure and nitrogen fixing bacteria on some essential oil components of coriander (Coriandrum sativum). International Journal of Agriculture and Crop Sciences, 4 (12): 787 - 792.

6. Farooq Anwar, Muhammad Sulman, Abdullah Ijaz Hussain, Nazamid Saari, Shahid Iqbal and Umer Rashid (2011). Physicochemical composition of hydro-distilled essential oil from coriander (Coriandrum sativum L.) seeds cultivated in Pakistan. Journal of Medicinal Plants Research, 5 (15): 3537 - 3544.

7. Garg V. K. (2007). Effect of non-symbiotic microbial inoculants on growth, yield and quality of fennel (Foeniculum vulgare Mill.) grown in sodic soil. Journal of Spices and Aromatic Crops, 16 (2): 93-98.

8. Gharib Fatma A., Lobna A. Moussa and Osama N. Massoud (2008). Effect of compost and bio-fertilizers on growth, yield and essential oil of Sweet Marjoram (Majorana hortensis) plant. International Journal of Agriculture and Biology ISSN Print: 1560-8530; ISSN Online: 1814-9596.

9. James A. T. and A. J. P. Martin (1951). Gas - Liquid Partition Chromatography: the separation and micro-estimation of volatile fatty acids from formic acid to dodecanoic acid. National Institute for Medical Research, Mill Hill, London, N. W. 7: 679 $-699$.

10. Jin X, J Sun, X Miao, G Liu and D. Zhong (2013). Inhibitory effect of geraniol in combination with gemcitabine on proliferation of BXPC-3 human pancreatic cancer cells. J Int Med Res, 41(4): 993 - 1001.

11. Kumar T. Senthil, V. Swaminathan and S. Kumar (2009). Influence of nitrogen, phosphorus and biofertilizers on growth, yield and essential oil constituents in Ratoon crop of Davana (Artemisia pallens Wall.). Electronic Journal of Environmental, Agricultural and Food Chemistry, ISSN: 1579 - 4377.

12. Lawrence B.M. (1993). A planning scheme to evaluate new aromatic plants for the flavor and fragrance industries. In: New crops. Janick J, Simon JE (eds), New York, Wiley, pp- 620 627.

13. Masada Y (1976). Analysis of essential oil by gas chromatography and mass spectometry, John Wiley and Sons Inc., New York, pp- $118-120$.

14. Minica DN, B Bozin, M Sokovic and N Simin (2004). Antimicrobial and antioxidant activities of Melissa officinalis L. (Lamiaceae) essential oil. J. Agric. Food Chem., 52(7): 2485 - 2489.

15. Momin Abidhusen H., Sawapnil S. Acharya and Amit V. Gajjar (2012). Coriandrum sativum- Review of advances in phytopharmacology . IJPSR. 3 (05): $1233-1239$.

16. Nadeem Muhammad, Faqir Muhammad Anjum, Muhammad Issa Khan and Saima Tehseen, Ahmed El-Ghorab, Javed Iqbal Sultan (2013). Nutritional and medicinal aspects of coriander (Coriandrum sativum L.) A review. British Food Journal, 115 (5) : $743-755$.

17. Polo MP and MG de Bravo (2006). Effect of geraniol on fattyacid and mevalonate metabolism in the human hepatoma cell line Hep G2. Biochem Cell Biol. 84 (1):102 - 11.

18. Silva Rivas da AC, PM Lopes, MM Barros de Azevedo, DC Costa, CS Alviano and DS Alviano (2012). Biological activities of $\alpha$-pinene and $\beta$-pinene enantiomers. Molecules, 17 (6): $6305-16$.

19. Small E. (1997). Culinary herbs. Ottawa, NRC Research Press, $219-25$.

20. Srinivasan V., S. Hamza and A. K. Sadanandan (2005). Evaluation of composted coir pith with chemical and biofertilizers on nutrient availability, yield and quality of black pepper (Piper nigrum L.). Journal of Spices and Aromatic Crops, 14 (1): 15 - 20. 
21. Vagionas K, K Graikou, IB Chinou, D Runyoro and O Ngassapa (2007). Chemical analysis and antimicrobial activity of essential oils from the aromatic plants Artemisia afra Jacq. and Leonotis ocymifolia (Burm. F.) Iwarsson var. raineriana (Vision 1) Iwars- son growing in Tanzania. Journal of Essential Oil Research, 19 (4): $396-400$.

22. http://www.mccormickscienceinstitute.com 